\title{
ANALISIS FAKTOR RESIKO PENYEBAB TERJADINYA DIABETES MELITUS TIPE 2 PADA WANITA USIA PRODUKTIF DIPUSKESMAS WAWONASA
}

\author{
${ }^{1}$ Richardo Betteng \\ ${ }^{2}$ Damayanti Pangemanan \\ ${ }^{3}$ Nelly Mayulu
}

\author{
${ }^{1}$ Kandidat Skripsi Fakultas Kedokteran Universitas Sam Ratulangi \\ ${ }^{2}$ Bagian Fisiologi Fakultas Kedokteran Universitas Sam Ratulangi \\ ${ }^{3}$ Bagian Gizi Fakultas Kedokteran Universitas Sam Ratulangi
}

\begin{abstract}
Diabetes mellitus type 2 is the most common form of diabetes. Approximately 9.7 million women in the United States were diagnosed with diabetes. Indonesia placed the sixth biggest diabetics rank in the world. Diabetes mellitus type 2 often called as lifestyle diabetes because besides hereditary factors, environmental factors such as age, obesity, insulin resistance, diet, physical activity, and lifestyle may cause diabetes. This study aimed to analyze the causes of type 2 diabetes mellitus in productive aged women. This research was conducted using qualitative methods, which produce descriptive data in the form of writings based on informant interviews. There were 10 informants in this study consist of women aged 20-65 years who live around the Wawonasa health centers area. Conclusion: The results of this study were in the form of data from interviews about the risk factors of diabetes mellitus.
\end{abstract}

Keywords: diabetes mellitus type 2, productive aged women.

\begin{abstract}
Abstrak: Diabetes melitus tipe 2 merupakan tipe diabetes yang paling umum di temukan. Sekitar 9.7 juta wanita di Amerika terkena diabetes. Indonesia, masuk ke dalam peringkat 6 angka kejadian diabetes melitus terbanyak di dunia. Diabetes melitus tipe 2 sering juga di sebut diabetes life style karena penyebabnya selain faktor keturunan, faktor lingkungan meliputi usia, obesitas, resistensi insulin, makanan, aktifitas fisik, dan gaya hidup juga menjadi penyebab diabetes melitus. Untuk menganalisis faktor penyebab terjadinya diabetes melitus tipe 2 pada wanita usia produktif. Penelitian yang dilakukan menggunakan metode kualitatif, yang menghasilkan data deskriptif berupa tulisan hasil wawancara pada informan. Informan dalam penelitian ini adalah wanita berusia $20-65$ tahun yang berdomisi di daerah kerja puskesmas wawonasa berjumlah 10 orang. Simpulan: Hasil dari penelitian ini berupa data dari wawancara tentang faktor faktor resiko diabetes melitus.
\end{abstract}

Kata kunci: diabetes melitus, wanita usia produktif.

Prevalensi diabetes melitus meningkat secara global teristimewa menjadi perhatian di negara Asia. Perkiraan secara global 366 juta individu yang diabetes melitus. ${ }^{1}$ Penyakit tidak menular (PTM) terus berlangsung dan menjadi masalah besar kesehatan masyarakat di dunia yang bertanggung jawab terhadap kematian dan kesakitan. PTM menjadi kematian dan kecatatan di seluruh penjuru dunia. Perkiraan di tahun 2020 penyakit ini merujuk kepada kematian dari 7 orang dari setiap 10 orang di negara berkembang. ${ }^{2}$

Diabetes melitus tipe 2 merupakan tipe diabetes yang paling umum di temukan pada pasien di bandingkan dengan diabetes melitus tipe 1,diabetes gestasional dan, diabetes tipe lain. Mayoritas pasien diabetes melitus tipe 2 tidak bergantung pada insulin. Kelompok diabetes melitus ini merupakan akibat dari kurang beresponnya jaringan sasaran (otot, jaringan adiposa dan 
hepar) terhadap insulin. ${ }^{3}$

Sekitar 16 juta orang di Amerika terdiagnosis diabetes. Prevalensinya adalah $6 \%$ sampai $7 \%$ pada orang usia 45 sampai 65 tahun dan sekitar $10 \%$ sampai $12 \%$ pada orang yang berusia lebih dari 65 tahun. Sekitar 90\% diantaranya menderita diabetes tipe $2 .{ }^{4}$ Sekitar 9.7 juta wanita di Amerika terkena diabetes. Diabetes tipe 2 berkembang pada semua umur bahkan pada masa anak maupun remaja. ${ }^{5}$

Indonesia, masuk ke dalam peringkat 6 angka kejadian diabetes melitus terbanyak di dunia.Dalam Diabetes Atlas 2000 (International Diabetes Federation) tercantum perkiraan penduduk Indonesia diatas 20 tahun sebesar 125 juta dan dengan asumsi prevalensi DM 4,6\%, diperkirakan pada tahun 2000 berjumlah 5,6 juta. Berdasarkan pola perambahan penduduk seperti ini, diperkirakan pada tahun 2020 nanti akan ada sejumlah 178 juta penduduk berusia diatas 20 tahun da dengan asumsi prevalensi DM sebesar 4,6\% akan didapatkan $8,2 \%$ juta pasien diabetes. Temuan kasus diabetes melitus lebih banyak di daerah perkotaan dari pada di desa. Dari hasil penelitian Waspdji menyebutkan kejadian diabetes di Jakarta dari tahun 1982 sampai 1992 mengingkat dari 1,7\% menjadi 5,7\%. Demikian pula di Depok, di temukan $6,2 \%$ penderita diabetes melitus. Selain di Depok, Manado juga masuk sebagai kota dengan jumlah penderita diabetes melitus terbanyak di indonesia., ${ }^{6,7}$

Diabetes tipe 2 merupakan penyakit multifaktorial dengan komponen genetik dan linkungan yang sama kuat dalam proses timbulnya penyakit tersebut.Pengaruh faktor genetik terhadap penyakit ini dapat terlihat jelas dengan tingginya penderita diabetes yang berasal dari orang tua yang memiliki riwayat diabetes melitus sebelumnya. ${ }^{1}$ Diabetes melitus tipe 2 sering juga di sebut diabetes life style karena penyebabnya selain faktor keturunan, faktor lingkungan meliputi usia, obesitas, resistensi insulin, makanan, aktifitas fisik, dan gaya hidup penderita yang tidak sehat juga bereperan dalam terjadinya diabetes ini.Perkembangan diabetes melitus tipe 2 yang lambat, sering kali membuat gejala dan tanda-tandanya tidak jelas. ${ }^{3,8}$ Melihat dari permasalahan yang terjadi di atas, peneliti tertarik untuk meneliti tentang "Analisis Faktor Resiko Terjadinya Diabetes Melitus Tipe 2 Pada Wanita Usia Produktif di Puskesmas Wawonasa"

\section{METODE PENELITIAN}

Rancangan penelitian ini mengunakan metode kualitatif, yang menghasilkan data deskriptif berupa tulisan hasil dari wawancara pada informan. Penetapan informan dengan cara consecutive sampling dengan kriteria wanita usia produktif $>20$ tahun dan $>65$ tahun, terdiagnosis diabetes melitus tipe 2 dan bersedia menjadi informan. Informan yang terlibat dalam penelitian ini berjumlah 10 orang

\section{HASIL PENELITIAN}

\section{Gambaran umum penelitian}

\section{Letak Geografis}

Kedudukan Puskesmas Wawonasa Kecamatan Singkil Kota Manado memiliki wilayah kerja sebagian dari wilayah pemerintahan Kecamatan Singkil dengna wilayah terdiri dari empat kelurahan dan dua puluh empat lingkungan.

Batas-batas wilayah kerja Puskesmas Wawonasa Kecamatan Singkl Kota Manado adalah sebagai berikut:

1. Sebelah Utara : Kelurahan Islam

2. Sebelah Selatan : Kelurahan Istqlal dan Kel. Komo Luar

3. Sebelah Timur : Kelurahan Singkil II dan Kel. Ternate Baru

4. Sebelah Barat : Kelurahan Sindulang

Keempat kelurahan di wilayah kerja Puskesmas Wawonasa Kecamatan Singkil Kota Manado dengan luas wilayah $\pm 105,5$ Ha masing-masing sebagai berikut:
1. Kelurahan Ketang Baru : $8 \mathrm{Ha}$
2. Kelurahan Karame : $12,3 \mathrm{Ha}$
3. Kelurahan Wawonasa : $21 \mathrm{Ha}$
4. Kelurahan Singkil I : $64,2 \mathrm{Ha}$ 


\section{Kependudukan}

Jumlah penduduk di wilayah kerja UPTD Puskesmas Wawonasa Kecamatan Singkil Kota Manado akhir tahun 2008 berjumlah 20.716 orang terdiri dari 10.386 orang pria dan 10.330 orang wanita.

Tabel 2. Data jumlah penduduk perkelurahan bulan Juni 2011

\begin{tabular}{cccccc}
\hline Kelurahan & $\begin{array}{c}\text { Luas } \\
\text { Wilayah } \\
\left(\mathrm{Km}^{2}\right)\end{array}$ & $\begin{array}{c}\text { Jumlah } \\
\text { Lingkungan }\end{array}$ & \multicolumn{3}{c}{$\begin{array}{c}\text { Jumlah } \\
\text { Penduduk }\end{array}$} \\
\hline Ketang & 8,0 & 5 & 1.671 & 1.740 & 3.411 \\
Baru & & & Pria & Wanita & Jumlah \\
Karame & 12,3 & 6 & 2.456 & 2.219 & 4.675 \\
Wawonasa & 21,0 & 6 & 1.886 & 1.966 & 3.852 \\
Singkil I & 64,2 & 7 & 4.373 & 4.405 & 8.778 \\
Jumlah & 105,5 & 24 & 10.386 & 10.330 & 20.716 \\
\hline \multicolumn{7}{l}{ Data sekunder } & & & & &
\end{tabular}

\section{Pendidikan}

Tingkat pendidikan masyarakat di wilayah kerja Puskesmas Wawonasa Kecamatan Singkil Kota Manado terdiri dari SD 18,94\%, SMP 27,85\%, SMA/SMK 28,31\% dan PTN/PTS 2,74\%.

\section{Sosial ekonomi}

Di wilayah kerjaPuskesmas Wawonasa Kecamatan Singkil Kota Manado masyarakatnya memiliki mata pencaharian yang beragam yang terdiri dari PNS, TNI/POLRI, dan pensiunan dengan persentasi sebanyak $35 \%$ dan $64 \%$ penduduk di wilayah tersebut bermata pencaharian sebagai buruh, nelayan, tukang dan petani

\section{Karateristik informan}

\section{Karateristik informan berdasarkan tempat tinggal}

Berdasarkan penelitian yang dilakukan di Puskesmas Wawonasa Kecamatan Singkil Kota Manado selama bulan November sampai Desember, diambil 10 wanita dengan riwayat diabetes melitus tipe 2 untuk menjadi Informan dalam penelitian.
Kesepuluh informan tersebut berasal dari keempat Kelurahan yang berada di wilayah kerja Puskesmas Wawonasa Kecamatan Singkil Kota Manado. Keempat Kelurahan tersebut ialah Kelurahan Ketang Baru, Kelurahan Karame, Kelurahan Wonasa, dan Kelurahan Singkil.

Tabel 3. Karakteristik informan berdasarkan tempat tinggal

\begin{tabular}{cc}
\hline Kelurahan & n \\
\hline Katang Baru & 2 \\
Karame & 2 \\
Wonasa & 4 \\
Singkil & 2 \\
Total & 10 \\
\hline
\end{tabular}

\section{Karateristik informan berdasarkan pendidikan dan pekerjaan}

Wawancara yang dilakukan pada kesepuluh informan di daerah kerja Puskesmas Wawonasa Kecamatan Singkil Kota Manado didapatkan data tentang pendidikan dan pekerjaan. Untuk pendidikan, 5 orang informan merupakan lulusan SMA/SLTA, 1 orang merupakan lulusan SMK, dan 3 orang merupakan lulusan SD. Untuk Pekerjaan yang terdata didapatkan 7 orang informan adalah ibu rumah tangga,2 orang PNS, dan 1 orang penjaga warung makan. Secara singkatnya kedua data tentang pendidikan dan pekerjaan kesepuluh informan tersebut dapat dilihat dalam tabel.

Tabel 4. Karakteristik informan berdasarkan pendidikan

\begin{tabular}{cc}
\hline Pendidikan & n \\
\hline SMA/SLTA & 5 \\
SMK & 1 \\
SD & 3 \\
Total & 10 \\
\hline
\end{tabular}


Tabel 5. Karakteristik informan berdasarkan pekerjaan

\begin{tabular}{cc}
\hline Pekerjaan & n \\
\hline Ibu Rumah Tangga & 7 \\
PNS & 2 \\
Penjaga Warung & 1 \\
Total & 10 \\
\hline
\end{tabular}

\section{HASIL}

\section{Gambaran faktor resiko diabetes melitus tipe 2}

\section{Usia}

Dalam penelitian ini, dari identitas informan didapatkan berusiausia termuda dari informan adalah 36 tahun dan usia tertua adalah 61 tahun.

Tabel 6. Karateristik informan berdasarkan usia

\begin{tabular}{cc}
\hline Informan & Usia (Tahun) \\
\hline 1 & 52 \\
2 & 55 \\
3 & 61 \\
4 & 39 \\
5 & 43 \\
6 & 53 \\
7 & 41 \\
8 & 36 \\
9 & 51 \\
10 & 56 \\
\hline
\end{tabular}

\section{Obesitas}

Salah satu faktor resiko DM tipe 2 adalah berat badan yang berlebih. Pada peneitian ini, faktor resiko DM tipe 2 didapatkandengan menghitung indeks massa tubuh (IMT) informan. Berdasarkan kriteria WHO (2000) berat badan seseorang dapat diklasifikasikan berdasarkan indeks massa tubuh.(17)
Tabel 7. Karakteristik informan berdasarkan IMT

\begin{tabular}{ccc}
\hline Klasifikasi & IMT & n \\
\hline Normal & $18,5-22,9$ & 3 \\
Berat Badan & $>23 ., 0$ & 1 \\
Berlebih & & \\
Beresiko & $23,0-24,9$ & 2 \\
Obese I & $25,0-29,0$ & 2 \\
Obese & $>30,0$ & 1 \\
II & & \\
\hline Total & & 10 \\
\hline
\end{tabular}

Ketika ditanyakan mengenai sejak kapan / umur berapa informan mengalami obesitas, sebagian besar dari informan menjawab setelah mempunyai anak atau berkeluarga. "waktu nona nona nyanda bagini kita, kita pe brat waktu nona nona Cuma 45. Itu waktu kita 17 taong, sampe kita so kaweng tetap bagitu kita pe brat. Nanti abis kaweng baru nae tu brat”. ada pula yang menjawab, " waktu nona nona badan kacili, nanti so berkeluarga kong ada ade baru nae. kira kira umur 25”. Dari informan lain juga menjawab,"kita nanti pas kaweng kong jadi basar, mulai melahirkan anak pertama kong mulai nae badan”.

\section{Makanan}

Kepada kesepuluh Informan diajukan pertanyaan berapa kali informan makan dalam 1 hari, mayoritas dari informan menjawab hanya 2 kali sehari. "kalo makang kadang 2 kali, kadang 3 kali. Tu smokol kwa cuma mo lia apa yang ada di meja. Kalo ada kita smokol, kalo nyanda, nyanda noh". Jawaban lain juga di ungkapkan informan lain, "kalo pagi so nda ja smokol kita, lantaran so nd ja riki. Masih ja rasa kenyang, abis ja ba rasa rasa makanan dang tu ja beking, nanti makang siang jam 12, deng nanti makang malam jam stenga 4, kalo nd riki makang sore makang malam noh jam 6”.

Ketika di tanyai mengenai berapa porsi yang anda habiskan sekali makan, jawaban bervariasi pun muncul dari kesepuluh informan. Ada yang menjawab, "so nda banya. Cuma sadiki sadiki komang. 
Pokoknya 1 sondo mar nda foll”. Ada juga yang menjawab, "kadang stegah porsi, kadang satu porsi, kalo skarang yang penting so makang so nda talalu doyan skali komang”. Informan lain juga menjawab, "makang skarang Cuma ja 1 falo falo, so ja tako makang banya".

Ketika pertanyaan apa apa saja jenis makan yang dikonsumsi oleh informan, mayoritas informan menjawab, nasi, lauknya ikan laut, dan sayur. Seperti jawaban salah satu informan,"hari hari makang nasi, kalo disini banya ubi, cm jarang ja makang, bagitu le deng mie deng roti. Kalo depe ikang ja pake ikang laut, kalo sayor, sayor tumis dang, kangkong, wortel, gedi, kalo daong ubi ada. ja santang dang”. Ada juga informan yang menjawab," nasi tetap musti ada biar Cuma sadiki, tetap musti ada, mo maag kalo nda makang nasi. Kong ja makang pake ikang laut deng sayor ja tumis noh, kangkong, yah daun daun”.

Untuk pertanyaan buah apa saja yang dikonsumsi informan, jenis apa dan berapa banyak, respon dari informan pun kebanyak menjawab setiap hari mereka mengonsumsi buah, yaitu pisang dan pepaya. Ungkap salah satu informan,"kalo buah banya kali, pisang deng popaya", Ada juga, "kalo buah ja makang, ja ambe di kobong, ja ambe pisang deng popaya”.

\section{Aktivitas fisik}

Data yang didapat untuk aktivitas fisik dari kesepuluh informan, didominasi dengan aktivitas memasak dan mencuci baju. 8 orang dari 10 informan menjawab demikian. Aktivitas tersebut sehubungan dengan pekerjaan dari kesepuluh informan yaitu ibu rumah tangga. 2 informan lainnya menjawab memiliki aktivitas bekerja kantoran setiap hari.

Tabel 8. Karateristik informan berdasarkan aktivitas fisik

\begin{tabular}{cll}
\hline Informan & n & \\
\hline Memasak dan Mencuci & 8 & \\
Bekerja Kantoran & 2 & \\
Total & 10 & \\
\hline Jawaban yang & berbeda & beda juga
\end{tabular}

diberikan oleh kesepuluh informan ketika ditanya mengenai apakah dalam berkativitas informan duduk dan berapa lama, ada yang menjawab,"tergantung noh, tergantung baju mo cuci”. Ada juga,"yah, kalo kita bobaso mulai jam 8 klar jam 10", ada juga yang menjawab "kalo ja momasa qt ja dudu 1-2 jam ada. apalagi kalo beking kukis, 3-4 jam ada itu”. Ada pula informan yang menjawab,"3 jam lebe ada. Cuma banya deng ba ketik kw”.

Kepada informan ditanyakan apakah dalam beraktivitas informan berdiri, Berapa lama informan melakukan aktivitas, jawaban yang berbeda beda pun muncul. Ada yang menjawab,"ada, ja ba strik dang, 3 jam ada. kadang le lebe. Cuma kalo kita pe kaki so manucu baru kita dudu”. Ada juga yang menjawab,"kalo badiri cuma ja ba jemur dang, tarolah satu stenga jam". Infoman lain juga ada yang menjawab, "sementara momasa kita ja badiri, kira kira satu jam”. Dengan singkat seorang informan menjawab, "yah, Cuma nda lama noh. Tarulah satu jam, stenga jam. Cuma mo beking ikang deng sayor kwa”.

Respon terhadap pertanyaan, apakah informan berolahraga teratur, jenis olahraga apa, seberapa sering, dan berapa jam per minggu. Jawab seorang informan, “yadoe,so nda ada waktu for mo olahraga. cuam tu ja bajalang dari pasar noh yang ja kita beking”. Ada yang menjawab,"so nyanda ada waktu”. Jawab informan lain,"nyanda sering, cuma ada. laengkali cuma bajalang". Ungkap innforman lainnya, "ada, 1 minggu 1 kali Ba bajalang, ada kalanya kalo kita mulai jam 6 ja abis jam 8”. Namum ada pula yang menjawab,"ada, setiap hari. Berjalan, paling paling tiap hari 1-2 jam ja bajalang”. Ada juga jawaban lain dari informan,"tiap hari kita, pas bangun pagi perenggangan 30 menit dulu baru ba angka dari koi”.

\section{Gaya hidup}

Gaya hidup yang dimaksud dalam penelitian ini meliputi kebiasaan konsumsi makanan beresiko, merokok, konsumsi alkohol. Untuk konsumsi makanan beresiko dalam penelitian ini antara lain: jeroan, makanan yang asam, dan minuman berkafein. 
Informansi yang didapatkan ketika pertanyaan apakah informan mengonsumsi jeroan, tetelan, seberapa sering, dan berapa banyak ketika di tanyakan ke kesepuluh informan, ada yang menjawab,"tetelan ada ja makang, kalo ja makang mie, ja bage tetelan. Kalo pun nyanda ada, nyanda ja paksa cari”. Jawaban yang berbeda pun di berikan informan yang lain, dan jawaban ini menjadi jawaban yang paling banyak di berikan para informan,"nda ja makang tetelan kita. Kalo makang bakso Cuma mie deng depe bakso". Ada yang menjawab,"so tako makang daging kita”, jawaban informan lain juga,"nyanda, kalo ja makang bakso nda ja pake tetelan kita”.

Dari hasil wawancara kepada informan mengenai pertanyaan apakah informan mengonsumsi makanan yang asam, seberapa sering dan berapa banyak, 6 orang dari 10 informan menjawab bahwa kebanyakan dalam mengonsumsi makanan yang asam mereka mengonsumsi "gohu" (terdiri dari potongan pepaya dan diberi air kuah dari campuran asam jawa, gula merah/gula pasir, cuka, dan terasi) beberapa jawaban dari informan,"makang gohu. Raja kita. Mar kadang kadang, Cuma kalo so makang 2 sampe 3 kali makang”, ungkap informan lain juga,"biasa tu asam asam gohu. Kalo gohu kita sekali makang 3 cup. Tu biasa ja jual jual dang. Cuma nda satu kali makang”, jawaban lain dari informan," ada noh, ja bage yang gula merah, nimbole bage yang gula putih".

Untuk pertanyaan apakah informan mengonsumsi minuman berkafein, seberapa sering, dan seberapa banyak dari hasil wawancara didapatkan bahwa 3 dari 10 informan mengonsumsi teh, 4 dari 10 informan mengonsumsi kopi, 1 orang mengonsumsi keduanya dan sisanya tidak mengonsumsi keduanya. Jawaban yang diterima pun dari informan,"nah, kopi hari hari. 1 hari boleh 2 mug basar, yang kopi brown dang”, ada juga jawaban yang didapatkan dari informan, "dulu kalo kita ja makang, kopi kita ja bage 1 mug basar”.

Untuk pertanyaan mengenai konsumsi rokok dan alkohol, mayoritas menjawab tidak mengonsumsi kedua duanya. Namun ada 1 orang informan yang mengonsumsi alkohol hanya untuk memanas tubuh,jawaban yang diberikan,"kita ja minum Cuma 1 sloki kwa, Cuma mo sepanas kwa”. Dan ada 1 orang informan ditemukan dengan riwayat mengonsumsi rokok. 'Apakah anda memiliki kebiasaan merokok? qt ini dlu perokok berat. Nanti 7 bulan terakhir ini baru brenti. Sejak kapan anda mulai merokok? dari SMA. Berapa banyak batang rokok yang anda habiskan sehari? ohh, laeng kali sampe 3 bungkus, djisamsoe lagi. Bila sudah berhenti, sejak kapan anda berhenti? nanti 7 bulan terakhir ini baru qt brenti'.

\section{BAHASAN}

Berdasarkan hasil penelitian yang dilakukan dengan teknik depth interview pada 10 wanita usia produktif di Puskesmas Wawonasa Kecamatan Singkil Kota Manado di jumpai kelima faktor faktor resiko yang di teliti, di yakini sebagai penyebab dari diabetes yang diderita kesepuluh wanita usia produktif di Puskesmas Wawonasa tersebut.

\section{Usia}

Diabetes Melitus dapat menyerang warga penduduk dari berbagai lapisan, baik dari segi ekonomi rendah, menengah, atas, ada pula dari segi usia. Tua maupun muda dapat menjadi penderita DM. Umumnya manusia mengalami perubahan fisiologi yang secara drastis menurun dengan cepat setelah usia 40 tahun. Diabetes sering muncul setelah seseorang memasuki usia rawan, terutama setelah usia 45 tahun pada mereka yang berat badannya berlebih, sehingga tubuhnya tidak peka lagi terhadap insulin. Teori yang ada mengatakan bahwa seseorang $\geq 45$ tahun memiliki peningkatan resiko terhadap terjadinya DM dan intoleransi glukosa yang di sebabkan oleh faktor degeneratif yaitu menurunya fungsi tubuh, khususnya kemampuan dari sel $\beta$ dalam memproduksi insulin. ${ }^{18}$ untuk memetabolisme glukosa.

Berdasarkan hasil penelitian yang di lakukan pada kesepuluh wanita usia 
produktif di Puskesmas Wawonasa, usia termuda ditemukan pada informan kedelapan, sedangkan usai tertua ditemukan pada informan ketiga. Hasil penelitian ini juga sejalan dengan penelitian yang dilakukan sebelelumnya oleh Ayu dan Indirawati yang mengemukakan bahwa, prevalensi DM di Indonesia pada penduduk usia > 15 tahun meningkat dari 1,5-2,3\% menjadi 5,6\% pada tahun 1993.(19) Hasil studi epidemiologi tentang DM di Manado juga menunjukan angka yang lebih tinggi yaitu $6,1 \%{ }^{7}$ sejalan dengan apa yang di kemukakan oleh Ayu dan Indirawati pada penelitiannya,

\section{Obesitas}

Obesitas bukan hanya mengundang penyakit jantung koroner dan hipertensi, tetapi juga diabetes melitus tipe 2. Obesitas merupakan faktor utama dari insiden DM tipe $2 .^{22}$ Obesitas dapat terjadi karna banyak faktor. Faktor utama adalah ketidakseimbangan asupan energi dan keluarnya energi. Obesitas juga melibatkan beberapa faktor, antara lain: genetik, lingkungan psikis, perkembangan, lifestyle, kerentanan terhadap obesitas temasuk program diet, usia, jenis kelamin, status ekonomi, dang penggunaan kontrasepsi khususnya kontrasepsi hormonal. ${ }^{23-27}$

Dari hasil wawancara didapatkan nilai dari berat badan dan tinggi badan informan sehingga di dapatkan indeks massa tubuh informan. Dari kesepuluh informan didapatkan informan kelima, keenam, dan informan kesembilan dengan IMT normal, informan kedelapan dengan berat badan berlebih. Informan keempat dan informan kesepuluh dengan IMT yang beresiko, informan kesatu dan kedua dengan IMT obesitas 1, sedangkan informan ketiga dengan obesitas 2 .

Obesitas yang dialami kesepuluh informan di karenakan oleh beberapa faktor, seperti faktor keturunan, faktor asupan, faktor kurang beraktivitas fisik, dan faktor hormonal. Dalam wawancara, informan kedelapan dan kesepuluh mengungkapkan bahwa obesitas atau kegemukan yang dialami berasal dari peyuntikan KB hormonal. Informan kesatu dan kedua memberikan jawaban bahwa kegemukan yang diderita berasal dari asupan makanan yang berlebihan. Informan ketiga memangapi pertanyaan tersebut menjawab apabila kegemukan yang dialami diwariskan oleh kedua orang tua. informan keempat menjawab akibat kurangnnya aktivitas fisik, sedangkan informan kelima, keenam, dan informan kesembilan memilik riwayat obesitas namum karena penyakit yang di derita sekarang, IMTnya turun menjadi normal.

Indeks masa tubuh secara bersama sama dengna variabel lainya mempunyai hubungan yang signifikan dengan diabetes melitus. Penelitian sebelumnya yang dilakukan oleh Sunjaya, menemukan bahwa individu yang mengalami obesitas mempunyai resiko 2,7 kali lebih besar untuk terkena diabetes melitus dibandingkan dengan individu yang tidak mengalami masalah obesitas. ${ }^{18}$

Adanya pengaruh indeks masa tubuh terhadap diabetes melitus ini disebabkan oleh tingginya konsumsi karbohidrat, lemak dan protein sertaa kurangnya aktivitas merupakan faktor faktor resiko dari obesitas. Pengingkatan FFA ini akan menurunkan translokasi transpoter glukosa ke membrane plasma,dan menyebabkan terjadinya resistensi insulin pada jaringan otot dan adipose. $^{28}$

Insulin merupakan hormon yang diproduksi oleh sel-sel beta yang membentuk pulau sehingga disebut pulau langerhans di kelenjar pangkreas. Pada awalnya terbentuk proinsulin yang mlekulnya lebih besar daripada insulin. Proinsulin tersimpan di pankreas hingga dibutuhkan tubuh. Ketika proinsulin keluar ke peredaran darah, proinsulin diuraikan menjadi 2 bagian: peptida penghubung dan hormon insulin aktif. Fungis utama hormon insulin adalah menurunkan kadar glukosa di dalam sel. ${ }^{33}$

\section{Makanan}

Teori menyebutkan bahwa seringnya mengonsumsi makanan/minuman manis akan meningkatkan resiko kejadian DM tipe 
2 karena meningkatkan konsentrasi glukosa dalam darah. Riwayat pola makan yang kurang baik juga menjadi faktor resiko penyebab terjadinya DM pada wanita usia produktif yang sering di ungkapkan oleh informan. Makanan yang di konsumsi diyakini menjadi penyebab meningkatnya gula darah. Perubahan diet, seperti mengkonsumsi makanan tinggi lemak menjadi penyebab terjadinya diabetes, terutama di daerah daerah. ${ }^{27}$

Dari hasil wawancara, kesadaran akan penyakit diabetes melitus tipe 2 yang diderita oleh informan dapat dilihat dari pola makannya yang berubah, dimana mayoritas dari informan telah mengurangi waktu untuk makan, maupun mengurangi porsi makan itu sendiri. Penambahan variasi sayur yang dikonsumsi dan konsumsi buah setiap hari juga merupakan modifikasi pola makan yang diterapkan para informan setelah terdiangnosis DM tipe 2.

Semua penderita diabetes harus melakukan diet dengan pembatasan kalori, terlebih untuk penderita yang obesitas. Pemilihan makanan harus dilakukan secara bijak dengan melaksanakan pembatasan kalori, terutama pembatasan lemak total dan lemak jenuh untuk mencapai kadar glukosa dan lipid darah yang normal. Secara umum komposisi menu yang di rekomendasikan oleh WHO tahun 1990 terdiri 50-65\% karbohidrat, $25-30 \%$ lemak, dan 10-20\% protein. $^{28}$

\section{Aktifitas fisik}

Aktifitas fisik dapat mengontrol gula darah. Glukosa akan diubah menjadi energi pada saat berkatifitas fisik. Aktifitas fisik mengakibatkan insulin semakin meningkat sehingga kadar gula dalam darah akan berkurang. Pada orang yang jarang berolahraga, zat makanan yang masuk kedalam tubuh tidak dibakar tetapi ditimbun dalam tubuh sebagai lemak dan gula. Jika insulin tidak mencukupi untuk mengubah glukosa menjadi energi maka akan timbul DM. ${ }^{29}$

Rata-rata semua informan memiliki aktivitasnya masing-masing. Secara umum aktifitas fisik di bagi dalam tiga kategori, yaitu aktivitas Ringan, Aktivitas Sedang, dan aktivitas Berat. ${ }^{30}$ Pada Penelitian yang dilakukan, kesepuluh informan memiliki aktifitas fisik yang beragam.

Dari penelitian, data yang dapat dikumpulkan dari informan, memiliki aktivitas utama memasak, mencuci, dan bekerja sebagai pegawai negeri swasta dimana berdasarkan tingkatan dari The Netherland Nutrition Council, yang dikutip dari Baecke, kedua aktivitas tersebut termasuk kedalam aktivitas ringan. ${ }^{31}$

\section{Gaya hidup}

Saat ini, naiknya jumlah penderita obesitas dan perubahan gaya hidup menyebabkan semakin banyak orang yang menderita diabetes tipe 2 ini, di usia yang masih muda. Bahkan,bisa terkena diabetes melitus tipe 2 di usia 25 tahun. Tetapi, diabetes melitus tipe 2 ini bisa dicegah. Pertama kali yang harus dilakukan untuk mencegahnya adalah, menjaga makanan yang dikonsumsi dan menjaga kesehatan fisik tubuh.

Pakar penyakit DM Sidartawan Soegondo berpendapat bahwa peningkatan jumlah penderita diabetes yang cukup tinggi ini dipicu oleh gaya hidup yang tidak sehat yakni gerak fisik yang dilakukan. Gaya hidup seperti ini mudah menimbulkan kegemukan. Dengan berat badan berlebih, resiko seorang terkena diabetes juga semakin meningkat. ${ }^{32}$

Selain kurangnya aktivitas fisik yang dilakukan, konsumsi makanan beresiko, konsumsi alkohol dan rokok menjadi resiko diabetes melitus. Dari data hasil wawancara, didapatkan mayoritas dari informan tidak mengonsumsi alkohol dan merokok. Namun ada 1 orang yang mengonsumsi alkohol dengan intensitas waktu jarang, dan 1 orang dengan riwayat merokok

\section{SIMPULAN}

Dari hasil penelitian tentang faktor resiko penyebab terjadinya diabetes melitus yang dilakukan pada wanita usia produktif di Puskesmas Wawonasa periode 1 November - 29 Desember 2013 dapat disimpulkan sebagai berikut : 
1. Usia termuda informan dalam penelitian ini adalah 36 tahun dan yang tertua adalah 61 tahun.

2. Dari kesepuluh informan didapatkan 3 orang informan dengan IMT normal, 1 orang informan dengan berat badan berlebih. 2 orang informan dengan IMT yang beresiko, 2 orang informan dengan IMT obesitas 1 , sedangkan 1 orang informan dengan obesitas 2 .

3. Hampir dari kesepuluh informan mengonsumsi nasi, lauk (ikan), dan sayur setiap hari, dengan rata rata makan 2 kali sehari.

4. Dominasi aktivitas fisik kesepuluh informan adalah memasak dan mencuci, dimana menurut The Netherland Nutrition Council kedua aktivitas tersebut tergolong dalam aktivitas ringan.

5. Gaya hidup terdiri dari makanan beresiko, merokok, dan alkohol, dimana terdapat 1 informan yang mengonsumsi alkohol, dan 1 informan dengan riwayat merokok.

6. Kelima faktor resiko yang diteliti memiliki hubungan dengan kejadian diabetes melitus tipe 2 pada wanita usia produktif di puskesmas wawonasa.

\section{SARAN}

1. Bagi Pihak Puskesmas

a. Diharapkan dapat memberi penyuluhan dan pembinaan tentang penyakit diabetes melitus kepada masyarakat akan bahaya dan dampak akibat penyakit diabetes melitus dan arti pentingnya pola hidup sehat, makanan yang bergizi agar terhindar dengan penyakit diabetes melitus.

b. Diharapkan melakukan pemeriksaan penyaringan dengan kriteria Kelompok usia dewasa ( $>40$ tahun), Kegemukan berat badan (kg) $>120 \%$, Berat badan idaman atau Indeks massa tubuh $>27(\mathrm{~kg} / \mathrm{m} 2)$, Tekanan darah tinggi ( $>140 / 90$ mmHg), Riwayat keluarga DM, Riwayar kehamilan dengan berat badan bayi $>4000$ gram, Riwayat diabetes melitus pada kehamilan, Dislipidemia (HDL < $35 \mathrm{mg} / \mathrm{dl}$ atau Trigliserida >250mg/dl), Pernah toleransi glukosa terganggu atau Glukosa puasa terganggu yang bertujuan untuk mengidentifikasi mereka yang tidak bergejala.

2. Bagi Masyarakat

a. Meningkatkan kesadaran dan kewaspadaan terhadap kondisi kesehatannya dengan melakukan pemeriksaan diabetes.

b. Meningkatkan intensitas aktivitas fisik terutama bagi masyarakat yang aktivitas fisiknya rendah.

c. Menerapkan pola makan sehat dan bergizi seimbang.

d. Bagi masyarakat yang sudah DM agar berobat secara teratur dan selalu berkonsultasi ke poli gizi serta menerapkan cara hidup yang sehat.

3. Bagi Peneliti lain

Dapat melanjukan studi kualitatif ini dengan mencari hubungan faktor psikis terhadap terjadinya diabetes melitus. 